\title{
Exploring the Socio-Religious Feminist Struggle of South Asian Third- World Women Against the Labyrinthine Gossamer of Patriarchy in Selected Bangladeshi Fiction
}

\author{
Hassan Bin Zubair \\ $\mathrm{PhD}$ Scholar (English Literature)- Department of English-National University of Modern Languages- Pakistan \\ hbz77@yahoo. com
}

\begin{abstract}
This research explores the oppression of patriarchy on women in Muslim orthodox community in the light of Feminist Theory. The research draws on the basic assumption of feminism and shows the relationship between the religion and patriarchy. It shows how the relationship helps in the oppression of the females in the society. This research is qualitative in nature. On the surface level, the novel Wild Wind seems to be the documentation of the major characters of everyday life. However, a deeper analysis, while citing the non-western feminist critics like Margot Badran and her book Feminism in Islam and Anitta Kynsilehto and her book Islamic Feminism: Current Perspective and their position on feminism, this research asserts that the patriarchy in Muslim society is deeper than it seems. And Taslima Nasreen's account of her youthful life unveils the patriarchal codes and myths to subjugate the woman. On the surface, this book reveals Taslima's tumultuous youth in a patriarchal family and social structure. The book seems to recount the youthful experience of a rebellious girl; her experience of adult life and the minute detailing of a family relationship. But a deeper analysis shows not only patriarchy but also religion functions as an apparatus of repression for the women. Hence, the present research attempts at finding how patriarchy and Muslim religion are in complicit relation; how religion and patriarchy are making each other powerful making it more difficult for the women of Islamic society.
\end{abstract}

Keywords: Women, Feminism, Patriarchy, Oppression, Society, Religion.

\section{Introduction}

Taslima's novel Wild Wind is one of the most famous literary texts and a controversial novel too. Since, the publication of the novel, it has received numerous copious appreciation and criticism from different forum of critical scholarship. Different critiques viewed their opinions differently; however, this research attempts to focus on the patriarchal domination and exploitation of the characters in the novel and its impact on the individual and the society. Taslima Nasreen controversial because she not only criticizes the Islam religion but also narrates private life of the people. Shirshendu Mukhopadhya says that Nasreen has written this book only for her own benefit that is to earn money. According to him, she has business aspect in her mind. He comments:

"Taslima used her pen recklessly and hurt the sentiments of the common people. Also, Nasreen is an atheist. She was born in a Muslim family, but she became an atheist. Autobiographical books of Taslima raised controversy not only because of her criticism of Islam but also for narratives involving the private lives of the common people. Taslima candidly described her sexual relationship. She received criticism by progressive writers and intellectuals who described Wild Wind as a book written with the business aspect in the mind." (Mukhopadhya, 2004, p.34)

This view emphasizes Taslima Nasreen as the controversial writer. She was said to have inflicted insult on society and she could not stay in the city. Voll Kamth comments: 
"Nasreen's autobiographical writings have also proved to be provocative and have faced governmental sanctions in India as well as Bangladesh. She is accused of writing heinous and false facts about the most revered figure of Islam, Muhammad. She is criticized as an attention-seeker who is compulsively provocative and oversimplistic in her formulations on Islam and women. We condemned her for seeking trouble in India." (Kamth, 1998, p.16)

The view merely experiences the religious matter. The novel Wild Wind is considered as an anti-religious document. For these critics, Nasreen's writings are seeking trouble in her country and her religion. Critically examining the autobiographical book Wild Wind, next critic Mir Zohir Hussain claims:

"This is an insult to Muslims. She is an insult to Islam because she smokes and wears clothes that Islam does not approve of. Her writings carry the feelings of anti-religion, which will break the belief of Muslims towards Muhammad."

(Hussain, 2000, p.18)

Meer Nurul Islam is sympathetic towards Nasreen. According to him if we are angry towards bad norms and rules, we may raise tools. The tools such as axe, hammer and chisel to fight against such things but Nasreen has used her pain against such exploitations and, dominations. He argues:

"Within the bounds of our closed society, darkness reigns so strongly, that there is no fissure to let in light or air. If one cannot make a chink through a needle or nail on that wall of darkness, one can only use a spade, or an axe, or a hammer and a chisel bore holes for light. Taslima has used her pen to bring change in the society, which is appropriate." (Islam, 1991, p.7)

It is evident from the review of the criticism available on the novel that none of the critics has thrown light in the novel from the perspective of feminist theory. That is why; feminist theory is a newer perspective to look at the text that helps to excavate the sufferings and exploitations of the characters. Feminism conjures up various images and ideas regarding the women's issues. In spite of diversity, feminism often represented as a single entity and somehow concerned with gender equality and freedom. Lois Tyson defines patriarchy as:

"Patriarchy is thus, by definition sexist, which means it protects the belief that women are innately inferior to men. This belief in the inborn inferiority of woman is a form of what is called biological essentialism, because it is based on biological differences between the sexes that are considered part of our unchanging essence as men and women. A striking illustration is the word hysteria, which derives from the Greek word for womb and refers to psychological disorders deemed peculiar to women and characterized by overemotional, extremely irrational behavior." (Tyson, 2006, p.86)

This book Wild Wind deals with the issue of religion, gender inequality, the condition of a unemployed person in a society or even in his or her own house and many more perfectly. So, this book is not only an autobiography but also a document of a Muslim Orthodox society. The condition of Taslima and her mother and sister and all the female characters in her house is perfect example of gender inequality. This study makes significant contribution, mainly in the three areas of concern. First, this study brings in focus the relationship between patriarchy and religion especially in relation to Islam religion. For this, the researcher cites the examples of the holy Quran and analyzes in the light of new understanding womanhood and sexuality. Second, this research studies how patriarchy functions institutionally right from the family, with a case study of Taslima Nasreen and her family. Lastly, the study analyzes the testimony of a woman and highlights her space in an orthodox society. The patriarchal structure of the society and its outlook is reinforced by the religion. Most of the major religions have justified the subordinating position of the women. Male domination in the institutionalization and doctrine formation of the religion prove that they have made it in their favors. 
It has been institutionalized so strongly that any form of rebel from the side of women is crushed. The Wild Wind, when published in Bangladesh for the first time, angered the patriarchal and religious authority. The religious leaders blamed it for breaking the code of the Almighty by writing 'obscene' youth experience and questioning god's authority. It sees in the light of Muslim Feminist Margot Badran and western feminist Simon De Beauvoir's idea how the gender is construct to subjugate women and analyzes the role of Taslima along with other female character in her autobiography. Although this study makes significant use of the concepts developed in Muslim Feminist theory, it does not offer a comprehensive analysis of feminist theories. Rather the concepts developed by Margot Badran and Anitta Kynsilehto remain the primary tool of this analysis. Since the major objective of the study is to study the exploitation and the oppression of the major characters in the novel Wild Wind, the other issues remain outside the scope of this project. Given the nature of research, available time, and resources, this study does not offer any analysis of feminist theory in its holistic approach although such an analysis would definitely contribute towards unearthing the female conditions and pangs of sufferings.

\section{2. $\quad$ Research Objectives}

- To show the steps taken by Nasreen against her traditional culture, and her totalitarian family systems.

- To analyze the repression of women in Muslim Orthodox Community. It also reveals the position of women in Islam.

- To reveal the experience of women in its crude form which otherwise could have been fabricated in other literary genres.

- To show, how gender is constructed culturally from the childhood.

\section{Research Questions}

- What are the inherent causes of oppression and domination to the females in the society?

- How Muslim women are exploited and dominated in Muslim community, presented in Wild Wind?

\section{Theoretical Framework}

As this study reveals the oppression of women in Muslim society through Nasreen's Wild Wind, in terms of feminist theory, it follows the theory of Islamic Feminists like Margot Badran and Anitta Kynsilehto. Margot Badran's Feminism in Islam and Anitta Kynsilehto's Islamic Feminism: Current Perspective are the theoretical tools for the elaboration of this research. The fundamental goal of this study is to reveal the suppression and oppression of women in Muslim society. Therefore, my project tries to invent the sufferings and exploitation of the major characters in the novel. A critical lens of Muslim Feminist theory places the spotlight on the important ways in which the research reveals the pathetic condition of women in different society especially the Muslim society. This research also reveals the relationship of Muslim religion and feminism.

\section{Islamic Feminism}

Merlene LeGates in her book Their Time: A History of Feminism in Western Society finds it problematic to fix a particular date to the women's voice against patriarchal repression. "As historians have long recognized, neither women's consciousness of their own oppression nor the determination of individual and groups to combat it was dependent on the birth of modern terminology. This consciousness is what I have looked for in early feminism." (LeGates, 2001, p.15) 
However, what we generally understand is that the history of feminism is the history of feminist movement as well as its origin. Islamic Feminism that originated from 1980s and 1990s mainly focuses on the pangs and sufferings of the Muslim women whether they be in West or nonwest. The main purpose of Muslim feminism or Islamic Feminism is dismantling the gender inequalities prevalent in the society. Islamic Feminism has played major role in raising voice against the major social evils prevalent in the society. Ziba Mir-Hosseiniin her essay "Muslim Women's Quest for Equality: Between Islamic Law and Feminism" says:

"Many Muslim women and their life choices whether they live in an Islamic state or as part of a diaspora in a Western liberal state are governed and shaped by a set of patriarchal beliefs. Only the elite and the minority of highly educated women have the luxury of choice, of rejecting or challenging these beliefs and laws. A movement to sever patriarchy from Islamic ideals and sacred texts and to give voice to an ethical and egalitarian vision of Islam can and does empower Muslim women from all walks of life to make dignified choices. This, in the end, is what Islamic feminism is about." (Mir-Hosseini, 2008, p.645)

In this way, she talks about the Islamic Feminism and tries to define Islamic feminism in a new way. It was first introduced in Iran by writers like Mir Hosseini and Najmabadi. The term was used to describe a new feminist paradigm. Margot Badran writes:

"Islamic Feminism argues that woman may be heads of state, leaders, or judges. Islamic Feminism stands to benefit us all, Muslims of both sexes, as well as non-Muslims living side by side with Muslims everywhere."

(Badran, 2008)

In her book Feminism in Islam, Badran further analyzes and explains about Islamic Feminism. Islamic feminism helps to that woman who is caught in between the patriarchal norms and values. Islamic feminism helps woman understand their gender discrimination and the exploitation within the family. Souad Eddouada in her essay "Implementing Islamic Feminism" argues:

"With the growth of global religious fundamentalisms, rethinking religion has become a necessary path for feminist criticism within Muslim majority and minority Muslim countries. The achievement of a critique of religion from within, independently from the fundamentalist thought, is no longer a paradox, but a nowadays possibility. Accordingly, the deployment of social sciences tools of analysis is allowing Muslim feminists to build up multiple dialogic connections between Islam and feminism and disclaim both the orientalist and fundamentalist thesis of antagonism between an essential notion of Western feminism and a timeless Islamic patriarchy." (Eddouada, 2008, p.37)

In Women and Sexuality, Geetha Satpathy says, "Sex is considered a fact- one is born with either male or female genitalia. Gender is considered a social construction - it grants meaning to the fact of sex. Conversely, it could be said that only after specific meanings came to be attached to the sexes, did sex differences become pertinent" (Satpathy, 2000, p.45).

\section{Patriarchal Grounds}

Lois Tyson defines patriarchy as:

"Patriarchy is thus, by definition sexist, which means it protects the belief that women are innately inferior to men. This belief in the inborn inferiority of woman is a form of what is called biological essentialism, because it is based on biological differences between the sexes that are considered part of our unchanging essence as men and women. A striking illustration is the word hysteria, which derives from the 
Greek word for womb and refers to psychological disorders deemed peculiar to women and characterized by overemotional, extremely irrational behavior. "(Tyson, 2006, p.86)

Patriarchy fosters the gender-based inequalities that decide man as superior and woman as inferior, man as powerful and the woman as powerless. One of the American feminist Kate Millet sees, "Patriarchy as grotesque, increasingly militaristic, increasingly greedy, colonialist, imperialistic, and brutal, with a terrible disregard of civil liberties, of democratic forms" (Millet, 1970, p.511). Mary W. Wood in her book The History of Feminism defines patriarchy as:

"Patriarchy is a social system, in which the father or eldest male is the head of the household, having authority over women and children. Patriarchy also refers to a

system of government by male and to a system of government by male and to the dominance of men in a social or cultural system. It may also include title being treated through the male line." (Wood, 2001, p.12)

Lydia Falcon, a feminist critic in her article, "Feminism against Fundamentalism" says, "Patriarchy refers to the structure of society that is based upon the father ruled. Patriarchy is considered oppressive when it subordinates women at various levels by promoting masculine values and structures to maintain male privilege" (Falcon, 2001, p.4).

\section{Analysis}

The feminist reading of Wild Wind puts an eagle eye on the social evils and cultural dissimilarities in terms of freedom, education, job, and so many other things. It also describes Nasreen's revolt against her family, society, and men who have become obstacles in her natural and instinctual desire and dream fulfillment. Above all, it is a woman's search of love, freedom, identity, and independence, which is not given to her because she is a woman. That is why Nasreen goes against the norms and values of the society and religion. The novel deals with the problem of women in general and Nasreen herself in particular. Since, her child age she has been facing many problems. A sense of inequality, domination and hatred to the woman by the male dominated society makes her cross the boundaries made for woman. She is not allowed to do the works according to her wishes; she finds many partialities between son and daughter not only by other people even by her father too. Her father has discriminatory attitude towards his daughters. When she wants to celebrate her birthday, it is very difficult to know her exact birth date. Her mother could not remember and father has kept record of his sons' date only but not hers and her sister's. She searches everywhere in the house. She writes:

"There were two birthdates, Dada's and Chhotada's, written on the first page of father's book. There was no trace of Yasmin's (sister) and my birth dates or years in any corner of any one of the twelve hundred pages of the book. In fact, they

would not be found in any scrap of paper in the house." (Nasreen, 2006, p.2)

Taslima Nasreen's Wild Wind recounts her tumultuous youth in an orthodox Muslim society and a traditional family. The book documents her life from her early teen to the middle of her youth. She has very sharply observed the world around her and documented it very vividly. Family is the closest world she has; and its member are the characters she comes into regular contact. In the text Wild Wind, she has a father, medical doctor by profession; mother, a younger sister and two elder brothers. Except them significant part of the autobiography tells us about her lover-turned husband Rudra and her friends. As the autobiography covers a significant time of her life, we can see the gradual change in her outlook and attitude to deal with the rest of the world. The biography minutely details the relationship among the family members providing enough incidents to look at the social and family structure. Her account gives enough peepholes to look at the position of women in her family in particular and the whole society in general. The relation between her father and mother, her 
mother's status in the family, different familial code of conducts for herself and her brothers, her husband's outlook and the analysis of many other details makes it clear how latent patriarchy is operating in her family and society. Her sharp observation has already noticed the unequal and different status of her father and mother. She presents this unequal status of her mother and father in a very minute description. She writes:

"It had often happened that Ma would wash and fold Baba's clothes on the stand, clean and mop the room the whole day, open all the closed windows and doors so that fresh air and light could enter, move Baba's bed from the corner to near the window, and spread a clean sheet on it. She would then await Baba's return, hoping Baba would come, see and like her arrangements. Baba would come home." (Nasreen, 2006, p.253)

The Male Supremacy can be directly traced in her family. The source of ultimate economic and household power is exercised by Nasreen's father. Her father exercises the rights and freedom in her family and deprives other with even the basic things. The mother in the family plays subordinating role. She lacks economic independence. She is made to depend on her husband to run the family. She does not have a 'room' of herself. Therefore, she does not have the privacy of her, which makes her completely to depend upon father. Taslima notices it even in her early age. Once she describes a small feast of her sister's birthday:

"That day too, the one who did not get to share even a single piece of Yasmin's cake was Ma. She had left the house in the afternoon to return only at dusk. In her hand was a brown paper packet, inside which was a red colored dress material for Yasmin. Ma was going to stitch a frilled frock for Yasmin herself. Having no money, she had, without telling anyone borrowed some from Hashem mama, and gone to Gaurahi Cloth House and bought three yards of the material."

(Nasreen, p.9)

The most submissive woman in the autobiography seems to be the author's mother. She is the greatest sufferer of patriarchy. She is culturally programmed to have an outlook determined by patriarchy. She accepts her submissive role as a universal rule. She is isolated. She does not share collective experience with any of the family member. She seems to be a mere shadow of her husband. In spite of extreme negligence by her husband, she is worried lest he is not after any other woman. Nasreen wants to get cure physically, aesthetically as well as socially in the infected life caused by the patriarchal society. Nasreen is confined and infected within the patriarchal woven society. To get freedom and cure from such problems she writes poems, articles, and novels against bad norms of her religion and culture. she says:

"I did not follow all the rules and command of my father and culture. I went to see the world which I had not got chance to see before. The world meant the dozens of different people on the streets, the houses and courtyards of neighbors, the holy Tulsi corner ritual, the evening incense, and the singing of kirtans with the accompanying music of the cybals." (Nasreen, p.41)

Nasreen and her sister had been given limited space in the family. They both could not go outside alone if anything was to be done she had to take permission from her farther but her brothers were not in such rules, they were free to go anywhere outside where they like. Once a boy named Lutfer wrote a love letter to Taslima, after that she was kept strict by her father. She says, "I had to go school, escorted by guards. Borodada, grandfather was given the responsibility of escorting me to school in the morning, and taking me back home when school was over" (Nasreen, 2006, p.14). She believes that such types of boundaries limitations have been made for women because patriarchal society takes female as weak, emotional and so on. That is why she wants to be free from such things. The domination towards female is too much for her: she believes that superiority or authority is accorded in humanity but not to the sex. That is why she is not in a position to accept all the 
doctrines and paths made for her rather she wants her thoughts herself. She is no one in her society that is why she wants to assert her identity as a female. For this, she is ready to blur the boundaries created for the female. She believes that superiority or authority has been accorded in humanity not to the sex because men also can be inferior not only women. Some women are superior to men. It does not mean that once there is a man he always becomes superior and perfect. It is the eyes of male dominated society, which always hegemonies people to think men good and women bad. She writes, "Both men and women can be editors. Some words have incorporated some unjustified gender distinctions which I do not want to use" (Nasreen, p.224). She does not believe on Allah, Rasoo or to believe on Allah, for her, is the work of mindless people. It is illogical to respect and pray the God. When Nasreen's mother prays the Allah she says, "Ma couldn't possibly have any brains, otherwise why did she believe in Allah Rsoo? If she did, why did she sit alone with Aman Kaka in the room and whisper under the pretext of giving him advice" (75)? It means she does not believe in God. Not to respect the god, she is against her religion. She takes cigarette, goes out of the house in the parks, watches movies, reads storybooks, recites poetry, and writes verses. "All third rate magazines carrying pictures were banned at home" (99). But, she does not do as her father's saying. When someone scolds her and asks to follow according to her father's command she would say, "Yes, he is my father. He is not me. My father and I are different we have different interest" (Naseren, p.154). She wears the pants prohibited by her father. She does not like to wear 'odhna' to cover her face but her parents scold her. She writes, "I felt ashamed to wear this extra cloth to cover my breast. To me, this was the proof that something was hidden behind it, something soft, something modest, something one could not talk about. Whether I wore 'odhna' or not, people knew I had grown up" (Naseren, p.123). So, she threw her 'odhna', which her father had covered her with. Writing letters to the boys, making love affairs, visiting outside park, such things were not allowed in her culture but she goes beyond that and does everything she prefers. She is in love with a man called Rudra who is a poet. She meets him several times in the Botanical garden, Canteen, and hotel. She goes with Rudra and lies she had gone to meet Chandana her friend. She writes poems, articles, and stories against patriarchal society.

Nasreen, wants to make herself free from the restrictions of her society that is why she not only crosses the boundaries of her culture but she also writes poems, articles against patriarchal society in her own magazine called Shenjuti. She has a friend called Chandana who also likes freedom and ready to deny her parents' suggestions and rules of society so both of them write against dominations. Nasreen thinks that even the dresses made to women make them difficult in working because dresses like' Sari, Odhna etc. are difficult to wear. It disturbs while working. She, in this way, does not like to wear such dresses. She likes to wear the comfortable dresses that do not disturb while wearing and working. She, that is why, wore jeans in spite of her father's prohibition. "Put the buttons or zip in front not on the side. Put loops. If I want to wear a belt I will" (Nasreen, 2006, p.549). And she encouraged her sister to wear pants. She says, "wearing jeans did not mean she would become a boy" (Nasreen, 2006, p.549). In this way, she refuses the traditional concept of dresses for woman and she requests other too to wear the dress of their own. Nasreen's mother asks her to pray the God; she refuses because she has no faith in god. Her mother several times asks her to pray the Allah. She also nags her daughter all the time to respect the God. And she believes that if there is no respect and prey for Allah, he will get angry and the days of joys will end and the days if sorrow will begin. Painful life, sorrow, sadness everything is the result of not obeying Allah according to her mother. That is why she asks her daughter to prey and respect the Allah. Her mother says, "What are all these you are saying Nasreen? You have lost your faith!" (Naseren, 2006, p.528). 


\section{Discussion}

The patriarchy takes women as an object. The male members think it is his right to do whatever he pleases to do with the body of a woman. In the case of Taslima, the oppression of a woman is so extreme that it is at the level of violence and sexual harassment even in the public places. The females in Mulsim society suffer a lot in patriarchal society. Males treat them as the aliens. She writes that she is sexually harassed before the public. This is common in the society where female's position is not valued. She seeks help from the family and other friends in the society. However, it is vain. Instead of getting help and support from the family, everyone ignores her. In a patriarchal family or in society boy child is preferred than a girl child. Because woman is seen as an inferior sex, parents want to have a boy. Taslima mentions an example of extreme hatred for girl child. Taslima has a friend Chandana whom she loves very much. But there is a heart rendering story behind her birth. In this case, Chandana is a Buddhist. But no matter what the religion is, the extreme hatred is seen in every community. Taslima gives the account of many women in her hospital labor room where women's anxiety and fear of child's gender is much more than the fear of delivery. There are feasts and sweets when a boy is born but wails and cry when a girl is born. Taslima describes many incidents in the present autobiography. Women's inferior role in the society is culturally produced and reinforced. This gets ever stronger because the decisive role in producing and reinforcing them is played by male. As they control over every social institution they make it even stronger.

\section{"However, if a daughter brought a complaint to Baba that her husband was beating her, Baba said, let him. Let the husband beat her, if he gave her a little daal and rice to eat from his earning, she should keep quiet and continue to look after her husband's household. This was the advice she was sent with. When a husband gave Talaq to his wife, and married for a second time, Baba was out to take away the husband's job." (Naseren, p.192)}

Women's biological role as a child bearer, household worker, and dependent on the husband's earning is reinforced in the aforementioned example. The author's father thinks the role of male and female is biologically determined. As a representative of patriarchal male, he boasts at earning money for his family. Similarly, the success to provide economic support to the family is seen as matter of pride. Not just because they earn money, they have right to oppress their wives.

\section{FINDINGS}

In a patriarchal ideology, good girls are those who do not violate the norms imposed by patriarchy. Lois Tyson writes, "It is patriarchy that will do the defining because both the roles are projections of patriarchal male desire: for example, the desire to own 'valuable' women suited to be wives and mothers, the desire to control women's sexuality so that men's sexuality cannot be threatened and the desire to dominate in all financial matter" (Naseren, p.90). According to this sexist category, Taslima is a "bad girl". She violates patriarchal sexual norms. She openly falls in a relationship with a poet Rudra. She lets it known by everyone in the family. Ironically, when her father makes extra marital affairs with Rajia, no one in the family calls him a "bad man". But when Taslima, as an adolescent girl falls in love with a man, she is called a "bad girl". In fact, women's feelings, perspective, and opinion do not count unless they are in tune with patriarchy. Consciously or unconsciously, women internalize that they are objects and their task is making their husbands pleased with their body. Of course, it is culturally programmed in their mind that they spent most of the time trying to find the way to please their husband. Taslima's mother tries to get attention of her husband by decorating herself with all the means at her disposal. The good girl is always talked about in the society. Lois Tyson writes, "To her are attributed all the virtues associated with patriarchal femininity and domesticity: she is modest, unassuming, self-sacrificing, and nurturing. 
She has no needs of her own, for she is completely satisfied by serving the family. She is the angel in the family" (Nasreen, 2006, p.90). So we can say that in a patriarchal society and family Taslima's mother is a good girl. The individual identity of a woman in a patriarchal society is quite impossible. The man wants woman to be a part of his identity. Taslima secretly gets married with the poet Rudra. The moment they get married Rudra starts imposing rule over her. As mentioned earlier, patriarchy defines girls in two categories in terms of their sexual norms. The woman who breaks the patriarchal defined norms are called bad girl. Ironically, the man who sleeps with a bad girl is never called a bad boy. Lois Tyson writes, "We use the negative word slut to describe a woman who sleeps with number of men while we use the positive word stud to describe a man who sleeps with number of women. So the persistence of repressive attitudes toward women's sexuality is still visible in the language" (Naseren, p.91). Sex related ethics are more concerned with the women.

In Taslima's case, patriarchal norms are supported by the Islam religion. As Quran says, "God was declared male, and man was declared to be created in His likeness. Eve became the symbol of temptation and sin. The woman was consequently judged as a less likely candidate for salvation and an everlasting life in heaven than man" (Naseren, p.176). Young Taslima and her religious mother often get involved in discussion about the sexist presumption of Islam religion. After she gets frustrated and isolated in the family, Taslima's mother finds a "preacher" at Peerbaari. She goes there to listen to the sermon and sometime takes her daughters too. But sharp and educated Taslima finds the inconsistencies in Quran and debates with her mother. Taslima Nasreen in her text Wild Wind writes, "How can you accept you will not get the seventy-two nymphs in heaven, only your husband will, just because he is a man! If you are a witness in court, your sole witness will not do, two women witness are required. Yet a single man's witness will be acceptable, two men are not required" (Naseren, p.528). There are enough evidences that reinforce patriarchal values that undermine the women in Quran which Taslima brings forth while discussing with her mother. While discussing the rationale of Nabiji's getting married to six year old girl, she tries to convince that it is not justifiable action.

In case of Taslima, she has got married to an educated and learned poet, whose poetry advocates the equality of all kinds. His name was Rudra. Although she is married, she does not live in her in-law's house. Whenever she and Rudra want to meet, they two visit hotel or sometimes in Rudra's room. She does not inform her parents and takes all the decisions alone. She does not want to remain under the pressure and restrictions in the family. She repeatedly does not care about her religion or her social conduct. She thinks that patriarchal system makes woman weak and feeble; unhappy and restricted. Her husband Rudra turns out to be a hypocrite who just pretends to be a man of knowledge. He unveils his patriarchal self the moment his male pride is hurt. Taslima cannot go further in the relationship. She demands a divorce. But he thinks that she is her 'property' and can't go without his consent. "You are my lawfully wedded wife, you have to listen to whatever I say, come out, or I will call the police. No son of swine will be able to stop me" (Nasreen, 2006, p.655). Ultimately, she gets divorce and deserts her husband because she wants equality in her every steps of life. Had she been the traditional woman, she would have tolerated all the difficulties in her life thinking that they were her duty and religion, but she does not do so. She neither believes on her religion nor her social norms and values. In this way, Nasreen tries to recognize the female rights and to learn the social institution and personal power relation between the sexes. Naturally male and female are not given their particular and specified roles but it is the culture, which makes male and female different in every steps and stages. The right of equality and justice goes to both men and women. When we cannot get equality, we come to face domination and exploitation there will be the revolution. 


\section{Conclusion}

The present research concludes that women are exploited and suppressed in the society where patriarchy rules in its highest point. Taslima Nasreen's autobiography Wild Wind exposes the oppression of patriarchy in an Islam family, which helps to understand that females have very pitiable and bitter experiences. They suffer a lot in a patriarchal society. On the surface, the book seems a mere documentation of the author's daily life along with her observation of the world around her, but a deeper analysis exposes it to be the testimony of the women' subjugation by patriarchy. The autobiography covers the life of Taslima from her early teenage to the adulthood. By exploring the life activities of Taslima Nasreen and her suffering, the research concludes that females are exploited and oppressed in most of the traditional societies. Muslim society takes the cover of Islam religion and in the name of God, Allah, women are subjugated and they suffer. The researcher read the autobiography minutely and analyzed it with feminist touch. Taslima not only details her everyday life but also observes the lives around her. Moreover, her minute detailing of the world around her, the relationship among the family members and her own personal life gives readers the peephole to look at patriarchal social structure. The autobiography cannot be read just as a first hand story of a controversial writer. It is a lively documentary of an orthodox society where every woman has to suffer the physical, mental, social, and economic oppression of patriarchy. The present autobiography is the representation of hundreds of other woman whose echoes are never heard nor tried to hear ever. Although the autobiography Wild Wind was banned right after its first publication in Bengali language, it arose the sensation all over the world. The blame was that the book contains the obscene content and its blasphemy. Above all the charge was that the book posed the challenge against God, social hierarchy, and ethics. The rationale put forward by the orthodox community for fatwa order against author itself proves that the book is exposing the inhuman oppression of the women in a patriarchal society. Thus, the book opens up the possibility of feminist reading of the text to unveil the oppression of patriarchy and to analyze the pitiable condition of women. The research dwells on the general agreed upon definition of patriarchy, its apparatus, functioning and tools. Furthermore, the research establishes how it is reinforced through many male dominated social institutions. Taking into account different ideas of feminism the research presents the general ideas on patriarchy. The researcher has analyzed the role of Islam in reinforcing the patriarchy in subjugating women. Giving the evidence of different women character and their collective experience of oppression, the researcher establishes that the autobiography exposes the tyrant patriarchy operating in Taslima's society and family. In the same way, the research presents the different social, political, and cultural institutions that shape and make the patriarchy stronger. Thus, while analyzing the autobiography Wild Wind from the perspective of Muslim feminism the researcher has found that the patriarchy is prevalent in the society and family of Taslima Nasreen. Though it seems a mere autobiography, the deeper analysis brings forth how patriarchy is operating in an Islam society. The male chauvinism rules until today by neglecting the roles of females in the society.

\section{References:}

[1] Badran. M, Feminism in Islam, London: One World Publication, (2008).

[2] Beauvoir. S. de, The Second Sex, London: Walflower Press, (1999).

[3] Eddouada. S, Implementing Islamic Feminism, Ed. Anitta Kynsilehto, Islamic Feminism: Current Perspective, Tampere: Juvenes, (2008).

[4] Falcon. L, The New Politics, Sydney: Black Swan Publication, (2001). 
[5] Hussain. M. Z, Novels in Pakistan, Islamabad: Khuftar Publishing House, (2000).

[6] Islam. M. N, Islam and Women, Tortures on Women, Bangladesh: New Circle, (1991), 7-8.

[7] Kamth. V, A Selective Memory, New Delhi: Oxford University Press, (1998).

[8] Kynsilehto. A, Islamic Feminism: Current Perspective, Tampere: Juvenes, (2008).

[9] LeGates. M, Their Time: A History of Feminism in Western Society, New York: Routletdge Publication, (2001).

[10] Millet. K, Sexual Politics: New York: Garden City Press, (1970).

[11] Mir-Hosseini. Z, Muslim Women's Quest for Equality: Between Islamic Law and Feminism Ed. Anitta Kynsilehto, Islamic Feminism: Current Perspective, Tampere: Juvenes, (2008).

[12] Mukhopadhya. S, Reading Taslima Nasreen and her Wild Wind, The Critical Review 4.1, (2004), 34-37.

[13]Nasreen. T, Wild Wind, New Delhi: Shristi Publication Distributors, (2006).

[14] Satpathy. G, Women and Sexuality, New Delhi: Orient Longman, (2000).

[15] Tyson. L, Critical Theory Today, New York: Routledge, (2006).

[16] Walby. S, Theorising Patriarchy, New York: Basil Blackwell, (1990).

[17] Wood. M. W, The History of Feminism, Paris: new wave Publication, (2001). 